\title{
Penggunaan Model Pembelajaran Snow Cube Throwing Berbasis Eksplorasi dalam Meningkatkan Kemampuan Intuisi Matematis Siswa
}

\author{
Nenden Mutiara Sari \\ Magister Pendidikan Matematika, Universitas Pasundan \\ Jalan Sumatera No. 41, Bandung, Jawa Barat, Indonesia \\ nenden.mutiara@unpas.ac.id
}

Artikel diterima: 27-01-2021, direvisi: 28-09-2021, diterbitkan: 30-09-2021

\begin{abstract}
Abstrak
Model pembelajaran snow cube throwing dikembangkan untuk melatih kemampuan intuisi siswa melalui kegiatan menebak/memperkirakan pola dari masalah-masalah eksplorasi yang diberikan. Sesuai dengan kekhasan model pembelajaran ini, siswa dapat berlatih banyak soal berbasis eksplorasi. Banyaknya soal-soal eksplorasi yang diberikan akan membantu siswa dalam mempertajam kemampuan intuisinya. Penelitian ini bertujuan menganalisis peningkatan kemampuan intuisi matematis yang mendapat pembelajaran SCTBE, eksploratif dan ekspositori ditinjau secara keseluruhan dan berdasarkan kategori sekolah. Penelitian ini merupakan penelitian kuasi eksperimen dengan rancangan non-equivalent pre-test and post-test control-group design. Populasi penelitian adalah siswa kelas VIII dari tiga sekolah di Kota Cimahi. Pemilihan sampel dalam penelitian kuantiatatif didasarkan pada teknik strata dan kelompok. Tes kemampuan intuisi matematis yang digunakan berbentuk uraian yang terdiri dari 5 soal. Hasil penelitian menunjukkan bahwa: Secara keseluruhan peningkatan kemampuan intuisi matematis siswa yang memperoleh pembelajaran snow cube throwing berbasis eksplorasi lebih baik dari siswa yang memperoleh pembelajaran eksploratif dan ekspositori; ditinjau berdasarkan kategori sekolah, pembelajaran snow cube throwing berbasis eksplorasi lebih cocok digunakan pada sekolah kategori tengah yang memiliki karakteristik aktif dan mandiri.

Kata Kunci: pembelajaran eksploratif, intuisi matematis, snow cube throwing.
\end{abstract}

\section{The Use of Exploration-Based Snow Cube Throwing Learning Model in Improving Students' Mathematical Intuition Ability}

\begin{abstract}
The snow cube throwing learning model was developed to practice students' intuition ability through guessing/predicting patterns of the given exploration problems. Following the uniqueness of this learning model, students can practice many exploration-based questions. The number of exploratory questions given will help students sharpen their intuitive abilities. This study aims to analyze the improvement of mathematical intuition ability that obtained SCTBE, explorative, and expository learning reviewed as a whole and based on school categories. This research was a quasi-experimental study with a nonequivalent pre-test and post-test control-group design. The study population was class VIII students from three schools in Cimahi City. Sample selection in quantitative research is based on strata and group techniques. The mathematical intuition ability test used is in the form of a description consisting of 5 questions. The results showed that: Overall improvement in mathematical intuition ability of students who obtained snow cube throwing based on exploration learning was better than students who obtained explorative and expository learning; based on the school category, snow cube throwing based on exploration learning is more suitable for middle category schools that have active and independent characteristics.

Keywords: exploration learning, mathematical intuition, snow cube throwing.
\end{abstract}




\section{Pendahuluan}

Pemecahan masalah untuk beberapa waktu menduduki posisi penting dalam penelitian pendidikan matematika dan kurikulum matematika di berbagai negara (Setialesmana dkk., 2021). Membantu siswa menjadi pemecah masalah yang baik harus menjadi tujuan pembelajaran jangka panjang, sehingga berbagai upaya perlu dilakukan untuk mencapai tujuan pada tiap tingkatan kelas, setiap topik matematika, dan setiap pelajaran (Lester \& Cai, 2016).

Sejauh ini, telah banyak penelitian yang berusaha mengembangkan kemampuan pemecahan masalah, baik dengan menggunakan, model, metode, pendekatan, strategi pembelajaran dan penggunaan software dalam pembelajaran matematika (Lan, X., Zhou dkk., 2021; Wijaya dkk., 2021). Namun, hasil PISA 2018 menunjukkan bahwa Indonesia menempati rangking 72 dalam bidang matematika dari total 78 negara yang terlibat, dimana problem solving merupakan salah satu aspek yang diteskan dalam bidang matematika (OECD, 2018). Hal ini menunjukkan peningkatan kemampuan pemecahan masalah matematis siswa belum sesuai dengan harapan.

Cara yang paling efektif untuk belajar memecahkan masalah adalah dengan berlatih memecahkan banyak soal cerita (Amir dkk., 2021). Selain berlatih menyelesaikan masalah, siswa membentuk kesadaran intuitif dalam proses pemecahan masalah (Sipman dkk., 2021).

Paparan di atas menunjukkan bahwa seorang pemecah masalah yang baik tidak dapat terbentuk dalam satu malam. Dibutuhkan proses yang panjang untuk siswa berlatih berbagai jenis masalah matematis. Namun ada kemampuan yang dapat dilatih dari sejak dini, untuk menggapai tujuan tersebut. Salah satunya adalah kemampuan dalam membuat dugaan (intuisi). Usodo, (2011); Mudrika, (2013) dan Pratiwi, (2016) menyatakan bahwa penyebab rendahnya peningkatan kemampuan pemecahan masalah diantaranya karena siswa belum dapat memanfaatkan kemampuan intuisinya dalam menyelesaikan masalah.

Kemampuan intuisi memiliki peranan yang penting dalam menyelesaikan masalah matematis. Dane \& Pratt, (2009), menyatakan bahwa intuisi merupakan sarana untuk pemecahan masalah; sebagai pembuat keputusan moral; dan sebagai sarana untuk mengembangkan kreativitas. Selain itu, Wilder, (1967) mengungkapkan peranan intuisi proses penyelesaian masalah adalah untuk "tebakan", yang mungkin hasilnya benar atau salah; menurut Wilder, kemajuan tidak akan diperoleh tanpa tebakan dan bahkan salah menebak dapat menyebabkan kemajuan.

Peran kemampuan intuisi dalam meningkatkan kemampuan pemecahan masalah perlu mendapat perhatian mengingat kemampuan intuisi sebagai penunjang keberhasilan seseorang dalam menyelesaikan masalah matematis. Karena alasan tersebut diperlukan pendekatan pembelajaran yang dapat melatih kemampuan intuisi siswa. Salah satu pendekatan pembelajaran yang dianggap cocok untuk mengembangkan kemampuan tersebut adalah dengan menggunakan pendekatan eksplorasi. Alasan dipilihnya pendekatan ini adalah karena pendekatan eksplorasi merupakan kegiatan memperoleh pengetahuan melalui proses 
mengumpulkan data, mengolah data, menganalisis suatu pola atau informasi khusus, menentukan hipotesis, mencoba, kemudian menarik kesimpulan (Sari, 2015). Hal yang paling mencolok dalam kegiatan eksplorasi ini adalah pada bagian membuat hipotesis. Pada langkah ini, siswa dilatih untuk membuat dugaan penyelesaian dari permasalahan yang tengah dihadapi.

Meskipun begitu, belajar melalui eksplorasi pemecahan masalah tidaklah mudah. Siswa harus memiliki dasar pengetahuan awal yang baik dan mau terlibat secara langsung dalam kegiatan pembelajaran. Selama ini penerapan pembelajaran berbasis eksplorasi pada umumnya termuat dalam bahan ajar yang memuat langkah-langkah kegiatan eksplorasi, seperti penelitian (Anwar, 2012; Sari, 2015; Maryam \& Aeni, 2016; dan Huda, 2017). Pada beberapa penelitian di atas, bahan ajar eksplorasi disajikan dalam lembaran kertas HVS biasa. Peneliti menduga penyajian bahan ajar dengan cara tersebut, kurang menarik minat siswa dalam belajar dengan pendekatan eksplorasi. Akibatnya, banyak siswa yang tidak terlibat dalam kegiatan pembelajaran berdampak kurang optimal siswa dalam mengeluarkan kemampuan miliknya.

Upaya yang dilakukan untuk meningkatkan keterlibatan siswa perlu dilakukan agar pembelajaran eksploratif dapat berjalan dengan efektif. Siswa harus memaksakan diri untuk banyak berlatih banyak permasalahan guna mengembangkan kemampuan intuisi matematisnya. Salah satunya dengan melakukan perubahan cara penyajian bahan ajar, sehingga seluruh siswa dapat terlibat dalam kegiatan pembelajaran secara langsung. Oleh karena itu, penelitian ini peneliti menggunakan pembelajaran snow cube throwing yang dalam penelitian (Sari, 2010) dapat meningkatkan minat siswa dalam pembelajaran eksploratif.

Pembelajaran snow cube throwing dikembangkan dari model pembelajaran snowball throwing. Model ini dikembangkan agar siswa memiliki minat yang baik selama belajar matematika dengan pendekatan eksplorasi. Dengan model ini, peneliti berasumsi bahwa siswa akan berpartisipasi dan termotivasi untuk belajar dengan pendekatan eksplorasi dengan cara yang menyenangkan. Pembelajaran yang menyenangkan akan berdampak pada peningkatan hasil belajar siswa, sehingga harapan meningkatnya kemampuan intuisi siswa dapat terjadi.

Pembelajaran snow cube throwing berbasis eksplorasi (SCTBE) siswa memperoleh lima macam bahan ajar mengenai suatu konsep. Konsep tersebut terdiri dari beberapa masalah eksplorasi yang ditempelkan dalam beberapa kubus. Permasalahan tersebut dirancang agar siswa mengikuti langkah pembelajaran menggunakan pendekatan eksplorasi.

Pemilihan pembelajaran dengan pendekatan eksplorasi ini sejalan dengan pendapat Ben-Zeev \& Star, (2001) yang menyatakan bahwa pemilihan metode pembelajaran harus mempertimbangkan pada pengembangan kemampuan intuisi agar siswa dapat membuat koneksi antara pemahaman matematika informal dan formal. Melalui kegiatan eksplorasi, siswa difasilitasi untuk memperoleh pengetahuan dan keterampilan dan mengembangkan 
sikap melalui pembelajaran berpusat pada siswa (Ningsih, 2020). Selain itu, berdasarkan karakteristik pembelajaran dengan pendekatan eksplorasi, guru dapat melatih intuisi siswa selama proses pembelajaran melalui proses menebak pola dari masalah-masalah eksplorasi yang diberikan. Pemberian lima jenis bahan ajar dalam satu kali pembelajaran juga bertujuan untuk mempertajam intuisi siswa. Semakin banyak pengalaman siswa dalam menyelesaikan masalah, maka diharapkan semakin tajam pula intuisi siswa. Hal ini sejalan dengan pendapat Dane \& Pratt, (2009) yang menyatakan bahwa pemecahan masalah intuisi adalah proses pencocokan pola yang sering diasah melalui pelatihan dan praktik berulang.

Berdasarkan paparan di atas, peneliti menduga siswa dapat mempertajam kemampuan intuisinya bila siswa belajar dengan snow cube throwing berbasis eksplorasi. Karena itu, penelitian ini bertujuan mendeskripsikan peningkatan kemampuan intuisi matematis yang memperoleh pembelajaran SCTBE, eksploratif dan ekspositori menyeluruh dan berdasarkan kategori sekolah.

\section{Metode}

Metode yang digunakan pada penelitian ini adalah metode kuasi eksperimen dengan bentuk nonequivalent kontrol group design. Desain ini sama dengan pretest-posttest kontrol group design, hanya saja pada desain ini kelompok eksperimen dan kelompok kontrol tidak dipilih secara acak. Lokus dalam penelitian ini adalah di tiga Sekolah Menengah Pertama Negeri di Kota Cimahi. Pemilihan sampel dilakukan dengan menggunakan teknik strata dan teknik kelompok. Teknik strata digunakan untuk menentukan tiga sekolah dari tiga kategori sekolah yang ada, pada masing-masing kategori sekolah atas dipilih satu sekolah secara acak, sedangkan teknik kelompok digunakan untuk memilih tiga kelas dari setiap sekolah secara acak. Dengan demikian terdapat 9 kelas sampel yang terpilih. Jumlah siswa yang terpilih menjadi sampel dalam penelitian adalah 163 siswa kelas VIII.

\begin{tabular}{ccc}
0 & $x_{1}$ & 0 \\
0 & $x_{2}$ & 0 \\
\hline 0 & & 0
\end{tabular}

Penelitian ini membandingkan peningkatan kemampuan intuisi matematis dari tiga kelompok yang terdiri dari dua kelas kontrol dan satu kelas eksperimen. Perbandingan persamaan dan perbedaan perlakuan antara ketiga kelompok tersebut dijelaskan pada Tabel 1.

Tabel 1.

Perbandingan Persamaan dan Perbedaan Perlakuan antar Tiga Kelompok

\begin{tabular}{|c|c|c|c|}
\hline \multirow{2}{*}{ Perlakuan } & \multicolumn{3}{|c|}{ Pembelajaran } \\
\hline & $\begin{array}{c}\text { Snow Cube Throwing } \\
\text { berbasis Eksplorasi }\end{array}$ & Eksploratif & Ekspositori \\
\hline Bahan Ajar & $\begin{array}{l}5 \text { jenis bahan ajar berbasis } \\
\text { eksplorasi dalam } 1 \text { kali } \\
\text { pembelajaran }\end{array}$ & $\begin{array}{l}1 \text { jenis bahan ajar } \\
\text { berbasis eksplorasi } \\
\text { dalam } 1 \text { kali } \\
\text { pembelajaran }\end{array}$ & Bahan Ajar Biasa \\
\hline $\begin{array}{c}\text { Latihan } \\
\text { Soal }\end{array}$ & Soal-soal problem solving & Soal-soal problem solving & Soal-soal problem solving \\
\hline Penyajian & Ditempelkan pada snow & Dicetak dalam lembaran & Dicetak dalam lembaran \\
\hline
\end{tabular}




\begin{tabular}{|c|c|c|c|}
\hline Bahan Ajar & cube. & kertas HVS & kertas HVS \\
\hline $\begin{array}{c}\text { Proses } \\
\text { Pembelajar } \\
\text { an }\end{array}$ & $\begin{array}{l}\text { Diskusi secara } \\
\text { berkelompok mengenai } \\
\text { bahan ajar yang diberikan. } \\
1 \text { kelompok terdiri dari } 2 \\
\text { orang siswa. }\end{array}$ & $\begin{array}{l}\text { Diskusi secara } \\
\text { berkelompok mengenai } \\
\text { bahan ajar yang } \\
\text { diberikan. } 1 \text { kelompok } \\
\text { terdiri dari } 5 \text { orang siswa. }\end{array}$ & $\begin{array}{l}\text { Siswa memperhatikan } \\
\text { penjelasan guru, kemudian } \\
\text { mengerjakan soal-soal yang } \\
\text { diberikan guru. }\end{array}$ \\
\hline
\end{tabular}

Setiap kelas penelitian diberikan pre-test dan post-test (O) untuk melihat perbedaan kualitas peningkatan kemampuan intuisi matematisnya. Skor hasil pre-test dan posttest tersebut merupakan data penelitian yang digunakan untuk menguji hipotesis dalam penelitian ini.

Terdapat tiga variabel yang diteliti dalam penelitian ini yaitu variabel bebas, variabel terikat dan variabel kontrol. Variabel bebas adalah pembelajaran Snow Cube Throwing Berbasis Eksplorasi (SCTBE), Pembelajaran Eksploratif (EF) dan Pembelajaran Ekspositori (EI), sedangkan variabel terikat adalah kemampuan intuisi matematis (KIM). Variabel control dalam penelitian ini adalah kategori sekolah.

Untuk mengkaji lebih komperhensif tentang alasan rasional keterkaitan diantara variabel-variabel penelitian, peneliti melakukan pengkajian ditinjau dari kategori sekolah. Kategori sekolah yang terpilih dibagi menjadi tiga kategori yaitu atas, tengah, dan bawah berdasarkan hasil Ujian Nasional yang dikeluarkan oleh Dinas Pendidikan.

Instrumen yang digunakan dalam penelitian ini berupa tes kemampuan intuisi matematis berbentuk uraian yang disusun untuk mengukur peningkatan kemampuan intuisi matematis siswa sebelum dan sesudah proses pembelajaran pada materi lingkaran. Tes kemampuan intuisi matematis sebelum digunakan terlebih dahulu divalidasi oleh lima orang penimbang. Kelima penimbang diminta untuk memberikan saran atau masukan mengenai validitas isi dan validitas muka dari tes tersebut. Hasil uji validitas dapat dilihat pada Tabel 2 berikut:

Tabel 2.

Hasil Uji Penilaian Validitas Tes Intuisi Matematis

\begin{tabular}{cllll}
\hline $\begin{array}{c}\text { Banyak } \\
\text { Butir } \\
\text { Soal }\end{array}$ & \multicolumn{2}{c}{ Validitas Isi } & \multicolumn{2}{c}{ Validitas Muka } \\
\hline 13 & Cochran's & Asymp. & Cochran's & Asymp. \\
& $\mathrm{Q}$ & Sig. & $\mathrm{Q}$ & Sig. \\
\cline { 2 - 5 } & 4.000 & .406 & 4.000 & .406 \\
\hline
\end{tabular}

Dari Tabel 2 diketahui kelima penimbang memberikan pertimbangan yang seragam terhadap validitas muka dan isi tes kemampuan intuisi matematis yang dapat dilihat dari nilai sig. lebih besar dari 0.05. Semua penimbang menyimpulkan bahwa tes ini dapat digunakan. Hasil uji coba soal intuisi menunjukkan bahwa sebagian besar soal intuisi matematis termasuk kategori valid. Koefisien reliabilitas soal adalah 0,93 yang termasuk pada kategori sangat tinggi.

Teknik analisis data kuantitatif digunakan untuk membandingkan peningkatan kemampuan intuisi matematis siswa kelas eksperimen dan kelas kontrol, yaitu dengan menguji perbedaan rerata tiga kelompok sampel independen, yang didahului oleh uji normalitas dan uji homogenitas sebagai prasyarat uji parametrik. 


\section{Hasil dan Pembahasan}

Data yang dianalisis dalam penelitian ini adalah data KIM siswa kelas SCTBE, EF dan El dari kelompok sekolah kategori atas, tengah dan bawah. Deskripsi rataan NGain, deviasi standar data N-Gain KIM siswa disajikan dalam Tabel 3 berikut.

Tabel 3.

Deskripsi N-Gain KIM berdasarkan Pembelajaran

\begin{tabular}{|c|c|c|c|}
\hline \multirow[t]{2}{*}{ Statistik } & & \multicolumn{2}{|c|}{ N-Gain Pembelajaran } \\
\hline & SCTBE & Eksploratif & Ekspositori \\
\hline Rataan & 0,39 & 0,33 & 0.33 \\
\hline $\begin{array}{l}\text { Simpangan } \\
\text { Baku }\end{array}$ & 0,17 & 0,18 & 0,18 \\
\hline Jumlah Siswa & 93 & 83 & 87 \\
\hline
\end{tabular}

Dari Tabel 3 diperoleh informasi bahwa rataan N-Gain kelompok SCTBE lebih tinggi dibandingkan rataan $\mathrm{N}$-Gain kelompok EF dan El. Namun klasifikasi N-Gain ketiga kelompok tersebut termasuk pada kategori sedang. Diinjau dari aspek-aspek KIM, terdapat peningkatan rataan N-Gain KIM pada setiap aspeknya. Pada Tabel 4 dipaparkan rataan N-Gain KIM dari ketiga kelompok tersebut.

Tabel 4.

Deskripsi N-Gain Aspek-Aspek dalam KIM Siswa

\begin{tabular}{|lccc|}
\hline \multirow{2}{*}{\begin{tabular}{l} 
Kelompok \\
\cline { 2 - 4 }
\end{tabular}} & \multicolumn{3}{c}{ Aspek KIM } \\
\cline { 2 - 4 } & $\begin{array}{c}\text { Menebak } \\
\text { Fakta }\end{array}$ & $\begin{array}{c}\text { Menduga } \\
\text { Rencana }\end{array}$ & $\begin{array}{c}\text { Menduga } \\
\text { Solusi }\end{array}$ \\
\hline SCTBE & 0,59 & 0,15 & 0,37 \\
\hline Eksploratif & 0,49 & 0,12 & 0,38 \\
\hline Ekspositori & 0,42 & 0,11 & 0,38 \\
\hline \multicolumn{2}{c}{ Berdasarkan Tabel } & 4, siswa & yang
\end{tabular}
memperoleh pembelajaran SCTBE memiliki kemampuan yang lebih unggul dibandingkan pembelajaran EF dan EI dalam aspek menduga solusi. Pada aspek ini kualitas peningkatan ketiga kelompok tersebut sama-sama tergolong pada kategori sedang. Pada aspek menebak kata, rata-rata kualitas peningkatan antara pembelajaran SCTBE dengan pembelajaran EF dan El terlihat jauh berbeda.

Pada tahapan memahami masalah dalam pembelajaran SCTBE, siswa belajar untuk menebak unsur-unsur yang dibutuhkan dalam penyelesaian masalah. Dalam pembelajaran EF siswa hanya memperoleh satu jenis bahan ajar, dimana dalam satu kali pertemuan siswa hanya dilatih satu kali menebak fakta. Pada kelompok SCTBE siswa mendapatkan lima jenis bahan ajar, artinya siswa mendapatkan pengalaman belajar menebak fakta paling banyak dibandingkan kelas lainnya.

Sebelumnya telah dipaparkan bahwa peningkatan KIM kelompok SCTBE termasuk pada kategori sedang. Akan tetapi pada aspek menduga rencana, kelompok SCTBE memperoleh peningkatan yang rendah seperti dua kelompok yang lainnya. Rendahnya peningkatan pada aspek menduga rencana disebabkan karena siswa cenderung melewati langkah merencanakan solusi ketika menyelesaikan suatu masalah. Siswa lebih memilirkan solusi akhir dari suatu soal dibandingkan dengan strategi untuk menyelesaikannya. Walaupun peningkatannya tergolong rendah, namun rata-rata peningkatan KIM siswa SCTBE dalam aspek ini lebih tinggi dibandingkan dua kelompok lainnya.

Perbedaan peningkatan KIM antara kelompok tersebut, perlu dianalisis lebih lanjut apakah perbedaan tersebut signifikan atau tidak. Hasil uji Anova 1 Jalur telah dilakukan dirangkum pada Tabel 5.

Tabel 5.

Uji Perbedaan Rerata Peningkatan KIM Siswa berdasarkan Pembelajaran

\begin{tabular}{lllll}
\hline Pembelajaran & $N$ & df & F & Sig.
\end{tabular}




\begin{tabular}{|c|cccc|}
\multicolumn{1}{c|}{ SCTBE } & 93 & & & \\
\hline Eksploratif & 83 & 2 & 3.281 & 0,039 \\
\hline Ekspositori & 87 & & & \\
\hline
\end{tabular}

Berdasarkan data dari Tabel 5 diperoleh informasi bahwa hasil analisis data menyimpulkan $\mathrm{H}_{\mathrm{o}}$ ditolak. Dengan demikian dapat disimpulkan bahwa terdapat perbedaan peningkatan kemampuan intuisi matematis siswa diantara siswa yang memperoleh pembelajaran SCTBE, EF dan El. Selanjutnya, akan dilakukan uji beda lanjut untuk mengetahui pembelajaran mana yang lebih baik. Hasil uji perbedaan rerata peningkatan KIM antar pembelajaran dirangkum pada Tabel 6 .

Tabel 6.

Uji Beda Lanjut KIM antar Pembelajaran

\begin{tabular}{cccc}
\hline $\begin{array}{c}\text { Pengujian } \\
\text { Hipotesis }\end{array}$ & $\begin{array}{c}\text { Perbedaan } \\
\text { Rerata }\end{array}$ & t & $\begin{array}{c}\text { Sig. } \\
\text { (2-tailed) }\end{array}$ \\
\hline SCTBE : EF (A) & 0,055 & 2,088 & 0,038 \\
\hline SCTBE : EI (B) & 0,061 & 2,315 & 0,022 \\
\hline EF : EI (C) & 0,006 & 0,202 & 0,840 \\
Hasil pengujian hipotesis A dan B
\end{tabular}
menunjukkan bahwa $H_{\circ}$ ditolak. Dengan demikian dapat dikatakan rataan peningkatan KIM siswa yang memperoleh pembelajaran SCTBE lebih baik dibandingkan peningkatan KIM siswa yang memperoleh pembelajaran EF dan EI. Di sisi lain, hasil pengujian hipotesis $C$, menunjukkan bahwa $\mathrm{H}_{\circ}$ diterima. Artinya tidak terdapat perbedaan rataan peningkatan KIM yang signifikan antara siswa yang memperoleh pembelajaran EF dan El. Oleh karena itu, dapat disimpulkan bahwa peningkatan KIM siswa yang memperoleh pembelajaran SCTBE lebih unggul dibandingkan dua kelompok lainnya.

Unggulnya kelompok SCTBE dari dua kelompok lainnya diduga karena siswa SCTBE berlatih dalam membuat konjektur atau dugaan-dugaan terkait pola-pola yang telah diamati. Pengalaman ini, akan membantu siswa mengembangkan kemampuan intuisinya selama proses penyelesaian masalah. Pada pembelajaran eksploratif, siswa memperoleh bahan ajar yang sama dengan kelompok SCTBE, namun kelompok eksploratif memperoleh bahan ajar yang lebih sedikit dibandingkan kelompok SCTBE, sehingga hal ini mempengaruhi perbedaan kemampuan intuisi antara dua kelompok tersebut.

Dengan diberikannya lima jenis bahan ajar dalam pembelajaran SCTBE, siswa dapat berlatih banyak soal dalam satu kali pembelajaran. Meskipun pada kelas SCTBE siswa harus menyelesaikan 5 jenis bahan ajar, namun waktu yang dihabiskan untuk mengisi bahan ajar lebih singkat dibandingkan kelas eksploratif. Fakta tersebut sejalan dengan hasil penelitian Sari, (2017) yang menyatakan bahwa ketika suatu pembelajaran dikemas dalam suasana yang menyenangkan, maka waktu yang dibutuhkan untuk menyelesaikan bahan ajar menjadi lebih sedikit dibandingkan dengan pembelajaran yang relative membosankan bagi siswa.

Siswa pada kelas SCTBE memiliki sisa waktu yang dapat digunakan untuk berlatih banyak soal setelah menyelesaikan bahan ajar yang diberikan. Melalui banyaknya latihan, maka pengalaman siswa dalam menyelesaikan soal pun akan semakin bertambah. Dampaknya kemampuan intuisi siswa pun akan semakin meningkat.

Disamping itu pada pembelajaran El, siswa kurang berlatih membuat dugaandugaan seperti pada pembelajaran SCTBE dan eksploratif. Siswa lebih banyak berlatih 
soal-soal sesuai dengan contoh yang diberikan guru. Kebiasaan tersebut kurang melatih kemampuan intuisinya dalam menyelesaikan masalah. Hasil penelitian Vanlommel dkk., (2017) menunjukkan bahwa banyaknya pengalaman dan tingkatan usia berpengaruh terhadap cara seseorang mengambil keputusan. Dari pendapat tersebut, dapat ditarik suatu kesimpulan bahwa kemampuan intuisi seseorang akan berkembang seiring dengan bertambahnya pengalaman dan usia. Pendapat tersebut juga didukung oleh pernyataan Ben-Zeev \& Star, (2001) yang mengungkapkan bahwa kemampuan Intuisi matematis adalah hasil dari pengalaman yang diperoleh melalui interaksi dengan orang lain dan lingkungannya.

Pembelajaran SCTBE merupakan implementasi dari pembelajaran eksplortif yang disajikan melalui penerapan model pembelajaran snow cube throwing. Harapan dari pengembangan model tersebut adalah siswa dapat memperoleh pengetahuan melalui proses menemukan sendiri. Romiyansah dkk., (2020) berpendapat bahwa dalam belajar matematika, siswa harus memiliki kesempatan untuk memperoleh pengalaman melalui kegiatan penemuan konsep. Selain itu, siswa diharapkan dapat mendiskusikan hasil penemuannya di kelas.

Hal tersebut akan membantu siswa meningkatkan intuisi, kreativitas, pemikiran konvergen, serta untuk memperoleh kemampuan dalam merencanakan dan mengevaluasi.

Pada pembelajaran SCTBE siswa memperoleh lima jenis bahan ajar yang disajikan mengikuti tahapan pembelajaran eksploratif. Sipman dkk., (2021) berpendapat bahwa guru matematika dapat membantu siswa mengembangkan intuisi matematisnya dengan menyadari intuisi mereka, mengembangkannya, dan menggunakannya di kelas melalui pengajuan beberapa pertanyaan. Pertanyaan-pertanyaan eksploratif inilah yang pada akhirnya membantu siswa SCTBE dalam mengembangkan kemampuan intuisinya.

Selain itu, menurut Henden, (2004) (Exploration \& Exploitation) serta (Personality \& Experience) merupakan komponen-komponen yang dapat mempengaruhi Intuisi seseorang. Pembelajaran melalui kegiatan eksplorasi merupakan pembelajaran yang berpusat pada siswa. Pembelajaran ini menuntut siswa untuk lebih aktif dalam proses memperoleh pengetahuan. Selama proses tersebut, peserta didik akan terlibat dalam aktivitas intuitif seperti memecahkan masalah, menemukan prosedur matematika, dan merenungkan proses pemecahan masalah. Phan dkk., (2016) menekankan pentingnya keterlibatan siswa dalam kegiatan pembelajaran. Melalui keterlibatan dalam kegiatan pembelajaran, peserta didik akan memperoleh pengalaman intuitif.

Peningkatan KIM siswa EF seharusnya lebih unggul dibandingkan kelompok El. Akan tetapi, hasil penelitian menunjukkan bahwa peningkatan kelompok El lebih baik dibandingkan kelas EF. Hal tersebut diduga karena kurangnya keterlibatan siswa EF dalam mengikuti kegiatan pembelajaran eksploatif. Hal tersebut diperkuat oleh hasil angket dan wawancara yang menunjukkan bahwa penyerapan materi yang diperoleh siswa kurang optimal dalam pembelajaran 
EF karena kurangnya kemandirian serta keterlibatan siswa selama proses pembelajaran. Oleh karena itu pembelajaran SCTBE akan lebih unggul dibandingkan dua pembelajaran lainnya karena hasil angket dan wawancara menunjukkan bahwa siswa kelompok SCTBE menunjukkan ketertarikan selama proses pembelajaran.

Faktor ketertarikan tersebut menjadi salah satu penyebab siswa terlibat dalam poses pembelajaran. Adapun hal yang menyebabkan siswa tertarik dalam pembelajaran snow cube throwing adalah karena siswa dapat belajar sambil bermain. Kegiatan melempar kubus merupakan langkah dalam pembelajaran yang dianggap menyenangkan. Sari, N dkk., (2019) menunjukkan bahwa perbedaan cara penyajian bahan ajar memberikan perbedaan peningkatan kemampuan pemecahan masalah matematis siswa.

Selain membandingkan KIM ketiga kelompok yang telah diapaparkan sebelumnya, penelitian ini juga membandingkan KIM ketiga kelompok yang ditinjau dari kategori sekolah. Statistika deskriptif data KIM siswa dari ketiga kelompok siswa berdasarkan kategori sekolah disajikan pada Tabel 7.

Tabel 7.

Deskripsi Rataan N-Gain, Simpangan Baku KIM Siswa berdasarkan Pembelajaran dan Kategori Sekolah

\begin{tabular}{|clccc|}
\hline \multirow{2}{*}{$\begin{array}{l}\text { Kategori } \\
\text { Sekolah }\end{array}$} & \multicolumn{1}{c}{ Statistik } & \multicolumn{3}{c}{ N-Gain Pembelajaran } \\
\cline { 2 - 5 } & & SCTBE & EF & EI \\
\hline \multirow{1}{*}{ Atas } & Rataan & 0,32 & 0,40 & 0,45 \\
\cline { 2 - 5 } & Simpangan & 0,19 & 0,15 & 0,17 \\
& Baku & & & \\
\cline { 2 - 5 } & Jumlah Siswa & 30 & 31 & 27 \\
\hline \multirow{2}{*}{ Tengah } & Rataan & 0,46 & 0,28 & 0,21 \\
\cline { 2 - 5 } & Simpangan & 0,15 & 0,16 & 0,10 \\
& Baku & & & \\
\cline { 2 - 5 } & Jumlah Siswa & 31 & 25 & 30
\end{tabular}

\begin{tabular}{|lllll|}
\hline Bawah & Rataan & 0,39 & 0,32 & 0,34 \\
\cline { 2 - 5 } & $\begin{array}{l}\text { Simpangan } \\
\text { Baku }\end{array}$ & 0,16 & 0,20 & 0,17 \\
\cline { 2 - 5 } & Jumlah Siswa & 32 & 27 & 30 \\
\hline
\end{tabular}

Dari data yang termuat pada Tabel 7 diperoleh informasi bahwa rataan N-Gain KIM siswa kelompok SCTBE lebih tinggi dari rataan N-Gain KIM siswa kelompok EF dan El pada kategori sekolah tengah dan bawah. Akan tetapi, rataan N-Gain KIM siswa kelompok SCTBE lebih rendah dibandingkan dua kelompok lainnya hanya pada kategori sekolah atas. Walaupun begitu, signifikansi perbedaan peningkatan perlu diuji. Hasil perhitungan uji Anova 1 Jalur dan Kruskal Walis dirangkum Tabel 8.

Tabel 8.

Hasil Uji Perbedaan Peningkatan KIM antar

Pembelajaran berdasarkan Kategori Sekolah

\begin{tabular}{cccc|}
\hline $\begin{array}{c}\text { Kategori } \\
\text { Sekolah }\end{array}$ & $\begin{array}{c}\text { Perbandingan } \\
\text { Pembelajaran }\end{array}$ & $\mathrm{F}$ & Sig. \\
\hline Atas & SCTBE :EF :EI & 4,408 & 0,015 \\
\hline Bawah & SCTBE :EF:El & 1,350 & 0,265 \\
\hline $\begin{array}{c}\text { Kategori } \\
\text { Sekolah }\end{array}$ & Perbandingan & Chi- & Sig. \\
\hline Tengah & SCTBE : EF : El & 31,325 & 0,000 \\
\hline Hasil uji perbedaan peningkatan KIM
\end{tabular}

antar pembelajaran pada sekolah kategori atas menunjukkan bahwa siswa yang memperoleh pembelajaran El secara signifikan memperoleh peningkatan KIM yang lebih baik daripada siswa yang memperoleh pembelajaran SCTBE dan EF. Seperti yang telah diungkapkan sebelumnya, siswa pada sekolah kategori atas memiliki karakteristik yang kurang aktif selama kegiatan pembelajaran. Hal tersebut dapat dilihat dari pernyataan siswa yang menyatakan bahwa mereka lebih menyukai pembelajaran yang berpusat pada guru. Faktor inilah yang menyebabkan pembelajaran SCTBE dan EF 
tidak berjalan optimal dibandingkan pembelajaran El. Selain hasil angket dan wawancara, hasil observasi juga mendukung pernyataan bahwa siswa kategori atas kurang aktif dalam mengajukan pertanyaan selama kegiatan pembelajaran. Hal tersebut diakibatkan karena siswa kurangnya minat dan antusiasme siswa selama kegiatan pembelajaran EF dan SCTBE.

Hasil uji perbedaan peningkatan KIM antar pembelajaran pada kategori sekolah tengah menunjukkan bahwa pembelajaran SCTBE lebih unggul dibandingkan dua pembelajaran lainnya dalam meningkatkan KIM siswa. Hasil di atas menunjukkan bahwa dalam meningkatkan KIM, pembelajaran SCTBE lebih cocok diterapkan untuk siswa pada kategori sekolah tengah yang memiliki karakteristik aktif dan mandiri. Berdasarkan hasil angket dan wawancara siswa pada sekolah kategori atas cenderung lebih nyaman dengan pembelajaran ekspositori. Hal ini terlihat dari hasil wawancara siswa yang menyatakan bahwa siswa lebih nyaman dengan pembelajaran yang berpusat pada guru. Siswa menunjukkan sikap yang kurang antusias terhadap pembelajaran mandiri. Hal inilah yang menyebabkan hasil pembelajaran pada kelas EI lebih unggul dibandingkan kelas EF dan SCTBE.

\section{Penutup}

Berdasarkan hasil penelitian, dapat disimpulkan bahwa terdapat perbedaan peningkatan kemampuan intuisi matematis yang signifikan antara siswa yang memperoleh model pembelajaran snow cube throwing berbasis eksplorasi, pembelajaran eksploratif dan ekspositori.
Pembelajaran snow cube throwing berbasis eksplorasi memperoleh peningkatan yang paling tinggi dibandingkan dua pembelajaran lainnya. Berdasarkan pendapat para ahli, kemampuan intuisi seseorang akan semakin tajam apabila la memperoleh banyak pengalaman dan latihan. Model pembelajaran snow cube throwing berbasis eksplorasi memberikan siswa banyak pengalaman dalam menyelesaikan persoalan-persoalan matematis. Hal inilah yang diduga menjadi penyebab tingginya peningkatan kemampuan intuisi matematis siswa dibandingkan dua pembelajaran lainnya.

Umumnya dalam satu kali pembelajaran, siswa belajar satu konsep matematika dengan satu cara/ jenis saja. Hal ini mengakibatkan kurangnya pengalaman yang dimiliki siswa dalam menyelesaikan permasalahan. Namun melalui pembelajaran ini, siswa dapat belajar suatu konsep dengan 5 cara/ jenis yang berbeda. Selain itu penyajian bahan ajar dalam kubus, memberikan dampak yang berbeda terhadap peningkatan kemampuan intuisi matematis siswa dibandingkan penyajian bahan ajar dalam kertas HVS biasa. Penyajian bahan ajar dalam kubus dianggap menarik dan dapat menjadi suatu media yang dapat menampilkan 5 jenis bahan ajar yang berbeda dalam satu kali pembelajaran. Disisi lain, hasil penelitian ini ditinjau dari kategori sekolah menunjukkan bahwa pembelajaran snow cube throwing berbasis eksplorasi memperoleh peningkatan yang paling tinggi pada sekolah level tengah yang memiliki karakteristik aktif dan mandiri. Sebaiknya model pembelajaran snow cube throwing berbasis eksplorasi 
digunakan untuk siswa yang memiliki karakteristik aktif dan mandiri

\section{DAfTAR PUstaka}

Amir, N. F., Malmia, W., \& Taufik, T. (2021). Analisis Kemampuan Menyelesaikan Soal Cerita Matematika: Analysis of Ability to Solve Mathematics Story Problems. Uniqbu Journal of Exact Sciences, 2(2), 19-31.

Anwar, V. N. (2012). Pengaruh pembelajaran eksploratif terhadap peningkatan kemampuan penalaran, kemampuan komunikasi, dan karakter matematis siswa sekolah menengah pertama. Tesis Tidak Dipublikasikan, Bandung, UPI.

Ben-Zeev, T., \& Star, J. (2001). Intuitive mathematics: theoretical and educational implications. In Torff, B., \& Sternberg, R. J. (Eds.), Understanding and Teaching the Intuitive Mind: Student and Teacher learning (pp. 2956). Routledge.

Dane, E., \& Pratt, M. G. (2009). Conceptualizing and measuring intuition: A review of recent trends. International Review of Industrial and Organizational Psychology, 24(1), 140.

Henden, G. (2004). Intuition and its role in strategic thinking. Disertasi Tidak Dipublikasikan, BI Norwegian School of Management.

Huda, M. (2017). Meningkatkan kemampuan memecahkan masalah matematis siswa MAN Babat melalui strategi pembelajaran eksploratif. PRISMA Prosiding Seminar Nasional Matematika, 114-123.
Lan, X., Zhou, Y., Wijaya, T. T., Wu, X., \& Purnama, A. (2021). The Effect of Dynamic Mathematics Software on Mathematical Problem-Solving Ability. Journal of Physics: Conference Series. IOP Publishing, 1882(1).

Lester, F. K., \& Cai, J. (2016). Can mathematical problem solving be taught? Preliminary answers from 30 years of research. In Felmer, P. L., Pehkonen, E., \& Kilpatrick, J. (Eds.), Posing and solving mathematical problems (pp. 117-135). Springer.

Maryam, S., \& Aeni, A. N. (2016). Pendekatan eksploratif untuk meningkatkan kemampuan representasi matematis dan kepercayaan diri siswa. Jurnal Pena Ilmiah, 1(1), 551-560.

Mudrika, M. T. (2013). Profil Intuisi Siswa SMP dalam Memecahkan Masalah Geometri Ditinjau dari Kemampuan Matematika Siswa. MathEdunesa, 2(2), 1-8.

Ningsih, R. W. (2020). Respon dan Tanggapan Siswa terhadap Komponen dan Kegiatan Pembelajaran Matematika Menerapkan Pendekatan Eksplorasi-Elaborasi-Konfirmasi (EEK). Mandalika Mathematics and Educations Journal, 2(1), 32-42.

OECD. (2018). PISA 2018 results in focus.

Phan, T., McNeil, S. G., \& Robin, B. R. (2016). Students' Patterns of Engagement and Course Performance in a Massive Open Online Course. Comput. Educ, 95, 36-44.

Pratiwi, R. (2016). Profil intuisi siswa kelas IX SMP Negeri 3 Salatiga dalam memecahkan masalah kesebangunan 
ditinjau dari kecerdasan matematislogis, kecerdasan linguistik, dan kecerdasan visual spasial. Tesis Tidak Dipublikasikan, Surakarta, Universitas Sebelas Maret.

Romiyansah, R., Karim, K., \& Mawaddah, S. (2020). Analisis Kemampuan Koneksi Matematis Siswa Pada Pembelajaran Matematika Dengan Menggunakan Model Pembelajaran Inkuiri Terbimbing. EDU-MAT: Jurnal Pendidikan Matematika, 8(1).

Sari, N, M., Yaniawati, P., \& Kartasasmita, B. G. (2019). The Effect of Different Ways in Presenting Teaching Materials on Students' Mathematical Problem Solving Abilities. International Journal of Instruction, 12(4), 495-512.

Sari, N. M. (2010). Pengaruh Model Pembelajaran Snow Cube Throwing Terhadap Hasil Belajar dan Minat Siswa. Skripsi Tidak Dipublikasikan, Bandung, Universitas Pasundan.

Sari, N. M. (2015). Meningkatkan Kemampuan Pemecahan Masalah Matematis dengan Metode Eksplorasi. AlphaMath: Journal of Mathematics Education, 1(1).

Sari, N. M. (2017). The Effectiveness of Snow Cube Throwing Learning Model Based on Exploration. AIP Conference Proceedings, 1868(1), 050016.

Setialesmana, D., Sunendar, A., \& Katresna, L. (2021). Analysis of Students Mathematics Reasoning Ability in View of Mathematical Problem-Solving Ability. Journal of Physics: Conference Series. IOP Publishing, 1764(1), 012123.

Sipman, G., Martens, R., Thölke, J., \& McKenney, S. (2021). Exploring
Teacher Awareness of Intuition and How it Affects Classroom Practices: Conceptual and Pragmatic Dimensions. Professional Development in Education, 1-14.

Usodo, B. (2011). Profil Intuisi Mahasiswa dalam Memecahkan Masalah Matematika Ditinjau dari Gaya Kognitif Field Dependent dan Field Independent. Prosiding Seminar Nasional Matematika Dan Pendidikan Matematika, 95-102.

Vanlommel, K., Gasse, R. V., Vanhoof, J., \& Petegem, P. Van. (2017). Teachers' Decision-Making, Data Based or Intuition Driven? International Journal of Educational Research, 83, 75-83.

Wijaya, T. T., Zhou, Y., Ware, A., \& Hermita, N. (2021). Improving the Creative Thinking Skills of the Next Generation of Mathematics Teachers Using Dynamic Mathematics Software. International Journal of Emerging Technologies in Learning, 16(13).

Wilder, R. L. (1967). The role of intuition. Science, 156(3775).

\section{Riwayat Hidup PenUlis}

\section{Dr. Nenden Mutiara Sari, M.Pd.}

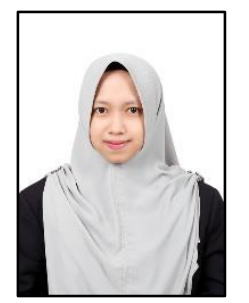

Lahir di Cimahi, 18 Juli 1988. Staf pengajar di Universitas Pasundan. Studi S1 Pendidikan Matematika Universitas Pasundan, Bandung, lulus tahun 2010; S2 Pendidikan Matematika Universitas Pendidikan Indonesia, Bandung, lulus tahun 2013; dan S3 Pendidikan Matematika Universitas Pendidikan Indonesia, Bandung, lulus tahun 2018. Reviewer Internasional Journal of Instruction terindeks Scopus Q2 tahun 2019. 